\title{
A multi-criteria approach for selecting the utility function of the historical building "Stara Polana" located in Zakopane
}

\author{
Małgorzata Fedorczak- Cisak ${ }^{1,}$, Alicja Kowalska ${ }^{1}$, Elżbieta Radziszewska - Zielina ${ }^{1}$, Grzegorz Śladowski ${ }^{1}$, \\ Filip Pachla ${ }^{1}$, Tadeusz Tatara ${ }^{1}$ \\ ${ }^{1}$ Cracow University of Technology, 24 Warszawska str., 31-155, Cracow, Poland
}

\begin{abstract}
In this article, the authors present a proposal for a hybrid decision model in order to select a utility function for a historic building, taking into consideration the criteria of the Małopolska Certificate of Energy Efficient Building as well as additional criteria for the comfort of the users. The description of the criteria and the proposed decision-making model focus on the Stara Polana historical building, which is located in Zakopane.
\end{abstract}

\section{Introduction}

According to the act of 23 July 2003 on the protection and care of historical monuments, a monument is a stationary property or movable property, its part or complex, that is man-made or is associated with human activity, being a testimony of a bygone era or event, the protection of which, due to its historical, artistic or scientific value, lies in its social interest (Article 3, point 1) [1,2]. According to point 1 , Article 6 of the act, immovable monuments should be protected and cared for, regardless of their state of preservation, this also applies to other building complexes, works of architecture and building, technical objects, industrial plants, etc. Sustainable development is an idea summarised in the very first sentence of the 1987 WCED report 'Our Common Future' (WCED Bruntland Commission, Our Common Future, Oxford University Press, Oxford 1987): "At the current level of civilisation, sustainable development is possible, it is such a development that meets the needs of the present without compromising the ability of future generations to meet their own needs" [3]. In Poland since 1997, this idea has found its legitimacy in Article 5 of the Constitution of the Republic of Poland of 2nd April, 1997- the content is as follows: "The Republic of Poland safeguards the independence and inviolability of its territory, ensures freedom and human and civil rights and citizens' safety, safeguards national heritage and ensures environmental protection, guided by the principle of sustainable development." [4] The Polish definition of sustainable development appeared only in 2001 in the act of 27 April 2001 on environmental protection law, where in Article 3, point 50 , it is specified that sustainable development is: "socio-economic development, in which the process of integrating political, economic and social activities takes

*Corresponding author: mfedorczak-cisak@pk.edu.pl place, preserving the natural balance and sustainability of the basic natural processes in order to guarantee the ability to satisfy the basic needs of individual communities or citizens of contemporary generation as well as future generations..." [5]. Additionally, in the act of March 2003 on spatial planning and development, in Article 1, point 50 on sustainable development are based: "the principles of shaping spatial policy by the units of local government and the government administration units as well as the scope and ways of proceedings in matters concerning allocation of land for specific purposes and setting the rules for their development..." [6]. In the Treaty of Lisbon (the Treaty of Lisbon amending the Treaty on the European Union and the Treaty establishing the European community), numerous references can be found regarding the relationship between the idea of sustainable development and cultural heritage. As examples of items of cultural heritage, immovable monuments, are therefore one of the elements of sustainable development of civilization and they play an important role in the strategy of sustainable development - this has been emphasised, for example, in the publication of the Polish Committee for UNESCO [2, 7]. Thus, as elements of the national heritage and a testimony to history, documenting the past, historical monuments should serve to foster and develop an enduring sense of community and national identity. Implementing the idea of sustainable development in the monument protection process emphasises their importance as objects of cultural heritage [8]. What is more, a comprehensive process of protecting historic buildings, for example by restoring their former functions or adding new roles, may be a part of the urban revitalisation process of a given urbanised area. In many European countries, the protection of cultural heritage is seen as a driving force in the urban development process. 
The system of administrative activities, EU subsidies and various tax incentives, encourage activities related to the protection of historic buildings - this promotes both the protection of cultural heritage and sustainable development [9]. In accordance with the idea of sustainable development, the policy of the European Union member states with respect to the building sector sets trends aimed at increasing the energy efficiency of both new and existing buildings [10]. In the area of thermal protection requirements for buildings, the standard of buildings 'of almost zero energy consumption' was introduced [11, 12]. Starting from 2021, all new buildings must meet stringent heat protection requirements. The problem is the huge number of existing buildings that consume much more heating energy than the new buildings. Historic buildings are released from the thermal protection requirements - these buildings often perform utility functions. Historic buildings, because of their character and historical functions, should follow thermal protection requirements that take into account many aspects - these aspects do not apply to buildings that are not monuments. Depending on their type of use, these requirements should take into account, among other factors, the internal environment parameters, adaptation to the function performed, technological possibilities of improving thermal protection, and financial considerations. Today, 76,189 monuments are registered in the Register of Historic Objects in Poland [13]. Many of these objects currently serve as residential or public utilities. They are also serve other functions. The owners and users of historic buildings often face a dilemma of how to modernise a historic building. There are no guidelines on how to improve the technical condition, especially with regard to thermal protection. There are also no tools that allow the user to choose the optimal function for a particular building on the basis of technical possibilities, historical, social or financial factors.

In this article, the authors present a model for selecting a utility function for historic buildings subjected to thermo-modernisation, taking into account the criteria of the Małopolska Energy Efficient Building Certificate [12] and additional criteria for the comfort of using the premises. The description of the criteria and the proposed decision-making model contained in this article focus on the Stara Polana historical building, which is located in Zakopane. The authors also suggested considering other criteria required for a full analysis of the problem, which were associated with social and economic aspects, as well as those related to the preservation of cultural heritage. A detailed description of these criteria, as well as a selection of the form of use for the analysed building, will be the subject of a separate article.

\section{Historic buildings in the context of improving energy efficiency while maintaining comfort and optimal functionality}

Historic buildings in Poland, depending on the area, are generally built using either timber or traditional brick technology. The technology a historic building was built with largely influences the choice of decisions related to the scope of renovation works. Construction works carried out at historic buildings are subject to specific formal and legal regulations. This is due to construction law [14] and the act of 23 July 2003 on the protection and care of monuments [1].

Technical conditions [15] do not regulate the requirements for improving the thermal insulation of these types of buildings. Decisions relating to the level of energy efficiency improvement of a historic building should depend on its current or planned function and should be considered individually for each object.

Another problem is the fact that the improvement of the technical condition of a given historic building is related to the reduction of the housing tightness (tight arrangement of the thermal insulation material, tight fitting of the joinery). This, of course, affects the internal environment conditions, such as temperature and humidity, which in turn, directly influence the thermal comfort of users. The thermal comfort of the internal environment, as well as energy efficiency, should be determined depending on the function of the historic building. Different comfort conditions are required for museums (on the basis of the works of art) and for buildings performing residential functions (on the basis of the residents).

There are no technical regulations related to the lighting of historic buildings. Lighting requirements are specified in [16] with regard to the minimum illuminance required by a given room, depending on its function.

Another factor that is important in the functions of historic buildings are vibrations. The vibration level is strongly dependent on the source of the vibrations, the location of the object, its technology and its function [41, 42].

In this article, the authors have performed an analysis of selecting the function of a building under the conservation protection - Villa 'Stara Polana' in Zakopane, taking into consideration the improvement of the building's efficiency as well as improvement to the comfort of users with regard to thermal comfort, lighting and vibrations. To build a tool for selecting the optimal function of a building, analytical tools and the authors' optimisation programme were used.

Criteria taken into account for the analysis of the selection of the utility function of the Stara Polana building are shown in Fig. 1. As the technical conditions do not specify requirements for historic buildings, the main criteria are the criteria for assessing buildings according to the Małopolska Energy Efficient Building (MEEB) Certificate [11]. Sub-criteria marked in green are used to assess buildings in accordance with the MEEB Certificate. Sub-criteria marked in blue are additional criteria and these take into consideration assessment of vibration, lighting and acoustic comfort. The criteria relating to the evaluation of financial, social and cultural heritage show a close relationship with the criteria analysed in this article. 


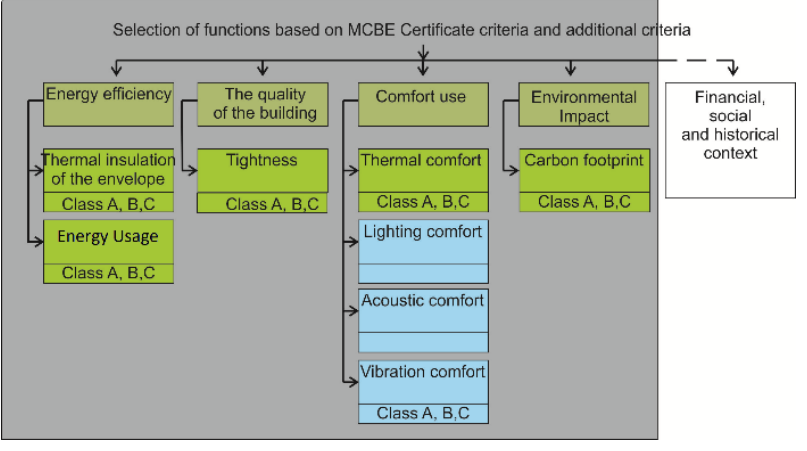

Fig. 1. Criteria adopted for the assessment of the Stara Polana building (own source)

Table 1 presents the division of the main and detailed criteria together with the limit values defining individual classes.

Table 1. Main and detailed criteria together with the limit values defining individual classes (own source)

\begin{tabular}{|c|c|c|c|c|}
\hline $\mathrm{M}_{\mathrm{x}}$ & $\begin{array}{l}\text { The main } \\
\text { criterion }\end{array}$ & $\mathrm{M}_{\mathrm{x}} / \mathrm{P}_{\mathrm{y}}$ & $\begin{array}{l}\text { Detailed } \\
\text { criteria }\end{array}$ & Limit values \\
\hline \multirow[t]{2}{*}{$\mathrm{M}_{1}$} & \multirow[t]{2}{*}{$\begin{array}{l}\text { energy } \\
\text { efficiency }\end{array}$} & $\mathrm{M}_{1} / \mathrm{P}_{1}$ & $\begin{array}{l}\text { coefficient } \\
\mathrm{U}\left[\mathrm{W} / \mathrm{m}^{2} \mathrm{~K}\right]\end{array}$ & $\begin{array}{l}>25 \% \text { - class } \mathrm{A} \\
>15 \% \text { - class B } \\
>5 \% \text { class } \mathrm{C}\end{array}$ \\
\hline & & $\mathrm{M}_{1} / \mathrm{P}_{2}$ & $\begin{array}{l}\text { coefficient } \\
\text { EU } \\
{\left[\mathrm{kWh} / \mathrm{m}^{2} \mathrm{a}\right]}\end{array}$ & $\begin{array}{l}>30 \%-\text { class } \mathrm{A} \\
>20 \% \text { - class B } \\
>10 \% \text { class } \mathrm{C}\end{array}$ \\
\hline $\mathrm{M}_{2}$ & $\begin{array}{l}\text { the quality } \\
\text { of the } \\
\text { building }\end{array}$ & $\mathrm{M}_{2} / \mathrm{P}_{1}$ & tightness & $\begin{array}{l}\mathrm{n}_{50}<1,51 / \mathrm{h}-\text { class } \mathrm{A} \\
\mathrm{n}_{50}<3,01 / \mathrm{h}-\text { class } \mathrm{A} \\
\mathrm{n}_{50}>3,01 / \mathrm{h}-\text { class } \mathrm{A}\end{array}$ \\
\hline \multirow[t]{4}{*}{$\mathrm{M}_{3}$} & \multirow[t]{4}{*}{$\begin{array}{l}\text { comfort of } \\
\text { use }\end{array}$} & $\mathrm{M}_{3} / \mathrm{P}_{1}$ & $\begin{array}{l}\text { thermal } \\
\text { comfort }\end{array}$ & $\begin{array}{l}-0.5<\mathrm{NPV}<+0.5- \\
\text { class A } \\
-0.7<\mathrm{NPV}<+0.7- \\
\text { class B } \\
-0.7>\mathrm{NPV}>+0.7- \\
\text { class C }\end{array}$ \\
\hline & & $\mathrm{M}_{3} / \mathrm{P}_{2}$ & $\begin{array}{l}\text { lighting } \\
\text { comfort }\end{array}$ & \multirow[t]{3}{*}{$\begin{array}{l}\text { depending on the } \\
\text { purpose of the room }\end{array}$} \\
\hline & & $\mathrm{M}_{3} / \mathrm{P}_{3}$ & $\begin{array}{l}\text { acoustic } \\
\text { comfort }\end{array}$ & \\
\hline & & $\mathrm{M}_{3} / \mathrm{P}_{4}$ & $\begin{array}{l}\text { vibration } \\
\text { comfort }\end{array}$ & \\
\hline $\mathrm{M}_{4}$ & $\begin{array}{l}\text { environme } \\
\text { ntal } \\
\text { impact }\end{array}$ & $\mathrm{M}_{4} / \mathrm{P}_{1}$ & $\begin{array}{l}\text { carbon } \\
\text { footprint }\end{array}$ & $\begin{array}{l}>30 \%-\text { class } \mathrm{A} \\
>20 \% \text { - class B } \\
>10 \% \text { class } \mathrm{C}\end{array}$ \\
\hline
\end{tabular}

\section{Choosing the optimal function of the Stara Polana building in relation to the assumed criteria}

\subsection{Description of the building and considered utility functions}

The Stara Polana building is located in the centre of Zakopane. The building is owned by Cracow University of Technology. Currently, the building is used as a hostel with a partial gallery function (painting exhibition). The building is located among the low-rise buildings on the main thoroughfare of Zakopane - Nowotarska Street. The building is a historic building, a villa in the Witkiewicz style, which was built in 1905 for the Płaza family by the builder Jan Ustupski-Kubecek. The object is a masonry and wooden structure. The basement is bricked, covered with stone and crowned with a brick-steel sectional ceiling. The ground floor, first floor and attic are made from wood.

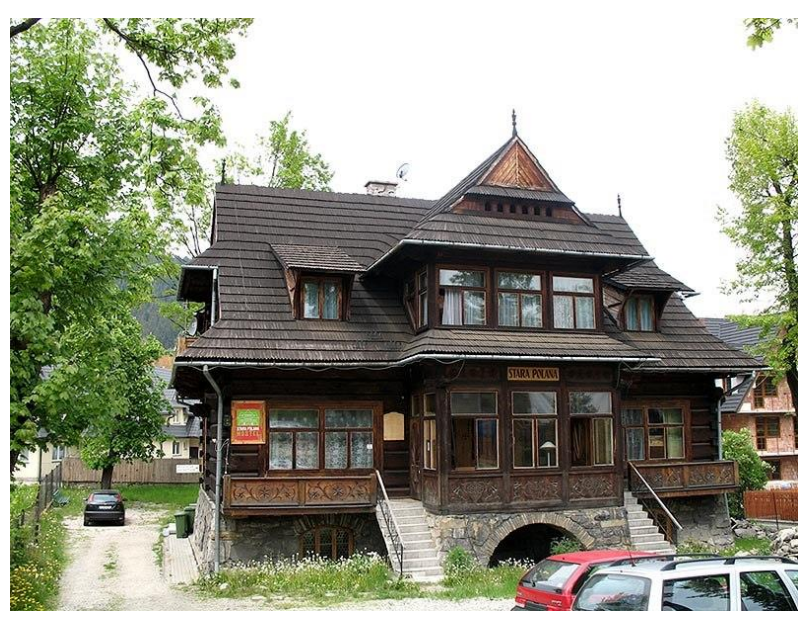

Fig. 2. A photo of the Stara Polana building in Zakopane (own source)

The owner plans restoration works including works aimed at improving the energy efficiency of the object. The renovation and thermo-modernisation works will depend upon the future function of the object.

For the purpose of analysis, the following variants were adopted regarding the functions of the object:

W1. Single-family residential building

W2. Multi-family residential building

W3. Public building - museum of Zakopane

W4. Public building - hostel

W5. Public building $-5 *$ hotel

W6. Public building - Shop (regional food products)

W7. Public building - Regional folk dance house

Variants W1 and W2 were proposed due to the original character of the object, which was designed as a villa (a residential building).

\subsection{A proposal for a multi-criteria hybrid approach to the selection of a utility function when adapting a historic building}

The problem of deciding the fate of a monument is the need to seek objective methods for identifying criteria that describe a historic building as well as methods for assessing their validity, allowing for the right choice from the available variants [17]. In the field of monument protection, many authors $[18,17,24,25]$ propose the use of multi-criteria decision support MCDA (multi-criteria decision analysis) for this purpose. These methods, making use of the expert opinions, allow for the processing of data on the values of attributes and indicators describing the historic object, as well as taking into account the choice of the best of the considered decisions - relative to the established criteria - in their analysis. All these elements are included in the form of a hierarchical or network dependency (relationship) model determining the direction or manner of conducting the analysis. Such an analysis allows for the integration and 
simultaneous processing of qualitative and quantitative information [19].

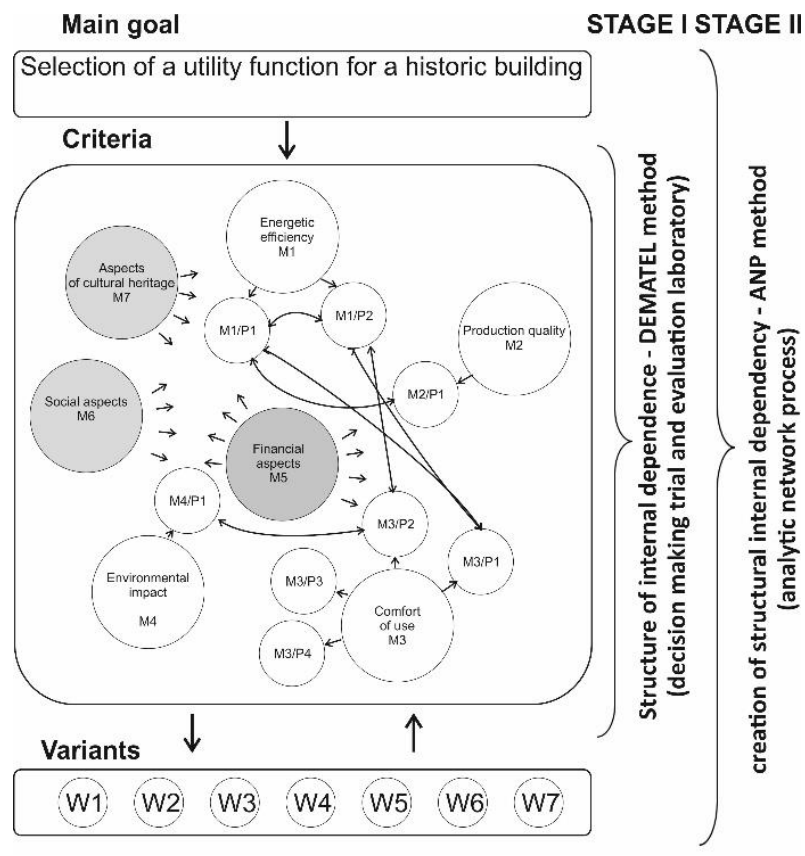

Fig. 3. Schematic diagram of a hybrid decision model for selecting a utility function for the Stara Polana historic building (own source)

As the basis of many methods of multi-criteria analysis lies the concept of the system as an object composed of various elements, [20] between which there are some relations (dependencies).

In the multi-criteria model, three types of dependencies will be considered (Fig. 3):

1. External simple dependence (hierarchical) organising components (main goal, criteria, variants) towards decreasing importance

2. Applied internal dependencies in the criteria component due to the observed fact of dependencies occurring between them

3. The use of feedback between criteria component and the component of function variants, as it is not only the validity of the criteria that determines the validity of the variants, but the variants themselves that affect the significance of the criteria

In the multi-criteria assessment, the essence of the hybrid approach is to conduct the analysis using mutually complementary methods that can initially be used separately. In connection with the above, it is proposed to use two known structural modelling methods arranged in the form of a hybrid for this purpose [21, 18]. Modelling and structural analysis in this case will consist of two stages:

Stage 1. To determine the dependence structure between decision criteria (internal dependence in the criteria set), it is suggested to use the DEMATEL (decision-making trial and evaluation laboratory) method [22]. In this method, the tool for modelling the dependence structure between criteria is a directed graph, the vertices of which symbolise the criteria while the arcs determine the relations (interactions) between them.
Stage 2. The ANP (analytic network process) method [23] is proposed to determine the array of the considered variants of the utility functions. The main goal of the ANP method is to determine the solution in the form of priorities for all possible external and internal dependencies as well as feedback between the network elements.

\subsection{Description of selection criteria based of the MCBE Certificate and the parameters of the building users' comfort.}

\subsubsection{Criterion - Energy efficiency}

The requirements for the thermal protection of buildings designed and built in Poland relate to both new buildings and existing buildings that are not historical monuments. These requirements are listed in Section $\mathrm{X}$ of the regulation on technical conditions for buildings and their location [15]. The requirements are imposed on the heat transfer coefficients of the envelopes (co-U) for existing buildings and additionally on the coefficient of nonrenewable primary energy (co-PE) for newly designed buildings.

Historic buildings and those under conservation protection are exempt from the requirements of thermal protection in the case of renovation works. This is due to many factors - in most cases, it is not possible to insulate the exterior walls of historic buildings; often, in the case of tenement houses, it is impossible to insulate the façade while the back elevation can be insulated. Historic buildings often located in urban environments (tenement houses, villas) do not have the option of replacing the system of heat supply (e.g. from coal-fired stoves to heat pumps). The scope of thermo-modernisation measures for such buildings should result from the nature of the object, technological possibilities and the economic calculation as well as from the function the building performs. Assessment classes due to the sub-criterion $\mathrm{M}_{1} \mathrm{P}_{1}$ (insulation of external walls) depend on the percentage improvement in thermal insulation. Even a small percentage improvement in the thermal insulation of the wall improves humidity conditions in the partition and on the internal surface. In the analysed Stara Polana building, when deciding about insulating the external walls, the fact that it is a historic building with external walls made of wooden logs must be taken into account. This excludes the possibility of insulation from the outside. Due to the historic nature of the building, there is no need to insulate it in such a way as to obtain very restrictive parameters of the thermal protection of the walls that would be at the expense of usable space. The level of energy efficiency improvement is determined according to the classes adopted for the assessment of buildings, which is compliant with MEEB Certificate for historic buildings (Table 1). The $\mathrm{M}_{1} \mathrm{P}_{2}$ criterion (coefficient for utility energy for heating and domestic hot water) is closely related to the improvement of the insulation of all envelopes as well as the replacement of heating and ventilation installations. Through the possibility of installing additional insulation of the attic, the 
replacement of windows and, above all, the replacement of coal-fired stoves with heat pumps, it is possible to save up to $60 \%$ of the energy consumption. This, however, is possible only in a few cases. Because of the historic character of the buildings, the improvement of the thermal insulation of the building envelope itself, usually preformed from the inside, provides around $30 \%$ of the energy with regard to heating and domestic hot water. Classes for the $\mathrm{M}_{1} \mathrm{P}_{2}$ sub-criterion are determined according to Table 1.

\subsubsection{Criteria for the comfort of using the rooms}

Energy consumption in buildings largely depends on the conditions designed for the internal environment (temperature, ventilation, lighting) and the exploitation of the building. The internal environment affects the health, performance and comfort of the users. The comfort of the rooms is as important as the energy efficiency. The environment where people stay must provide them with health and comfort for both work and rest. Both newly designed and existing buildings, depending on their operational possibilities, should meet the requirements according to Fig. 4 [26].



Fig. 4. The criteria considered in designing near zero energy buildings (own source)

Fig. 4 presents the main criteria for the design of energy-efficient buildings. In addition to the criteria related to energy efficiency, the designer should take into account the criteria for the comfort of use of energyefficient buildings, also shown in Figure 4.

In the case of historic buildings, design criteria depend upon many factors, such as their location within a city or the lack of the possibility to use renewable energy resources. When taking up renovation and thermomodernisation works, every effort should be made to obtain optimal comfort conditions depending on the present or future function the historic building is to perform.

In determining the comfort criteria, the authors took into consideration the assumptions of the MCBE certificate as well as the PN-EN 15251 standard [27] specifying comfort requirements for the internal environment.

\subsubsection{Criterion - Thermal comfort}

The requirements for providing thermal comfort are regulated by the PN-EN ISO 7730 standard - Ergonomics of the Thermal Comfort [28], using the calculation of PMV (predicted mean vote) and PPD (predicted percentage dissatisfied) index and the criteria of local thermal comfort. Thermal comfort is determined on the basis of measurements of temperature, humidity, air flow velocity, infrared radiation, user activity and the insulation properties of their clothing. Thermal comfort is closely related to the purpose of the building. It will be different in the case of residential premises, especially where the users are older people or children, and in the case of service functions. In the case of a museum room, priority should be given to comfort levels that ensure the preservation of the exhibits. Measurements of thermal comfort should be made in situ using instruments meeting the requirements specified in [29].

\subsubsection{Criterion - Lighting comfort}

In order to provide lighting comfort for the users, it is necessary to ensure proper lighting (without side effects such as glare and dazzle). The lighting requirements for the optimum lighting level, depending on the function of the object, are regulated by PN-EN 12464-1 standard 'Light and lighting. Workplace lighting. Part 1: Indoor workplaces' [16] by requiring a minimum illuminance depending on the function of the rooms. Example requirements are summarised in Table 2.

Table 2. Requirements for different types of room [27]

\begin{tabular}{|c|c|c|}
\hline No. & Rooms & $\mathrm{E}_{\mathrm{x}}[\mathrm{lx}]$ \\
\hline 1 & holiday rooms & 100 \\
\hline 2 & hotels, restaurants & 500 \\
\hline 3 & shops & 300 \\
\hline 4 & museums & 300 \\
\hline
\end{tabular}

Appropriate levels of illumination can be provided by daylight, artificial light or a combination of the two. For reasons of health, comfort and energy consumption, in most cases, it is recommended to use daylight (with additional lighting) instead of artificial lighting.

\subsubsection{Criterion - Vibration comfort}

The basic method for the evaluation of the influence of vibration on people residing in buildings is RMS (root mean square method) - this evaluation parameter is adopted, for example, in standards [31, 32, 33] and used by many researchers [e.g. $34,35,36,37$ ]. In [38], a measure of human perception of vibration strictly correlated the RMS method was proposed. The WODL ratio (in English, the human vibration perceptivity ratio HVPR), is the maximum ratio of the acceleration RMS value obtained from the analysis to the acceleration RMS value equivalent to the threshold for the perception of vibration by humans (in the same $1 / 3$ octave band) chosen from each $1 / 3$ octave band (formula 1 ).

$$
W O D L=\max \left(\frac{a_{R M S}}{a_{z}}\right)
$$

where:

aRMS - acceleration RMS value obtained from analysis; $\mathrm{a}_{\mathrm{z}}-$ acceleration RMS value equivalent to the threshold for the perception of vibration in a $\mathrm{z}$-direction in the same $1 / 3$ octave band as in a RMs. 
Values of the HPVR ratio could be listed in Table 3 according to the function of the building, but in reality, it is often more appropriate to consider the function of individual rooms rather than the building as a whole. For example, in hospitals there are wards and operating theatres which have different vibration perception comfort levels. Operating theatres have stricter requirements and the comfort level is equal to the perceptivity threshold of vibration $[30,31]$.

In this case, the following functions of the building are considered: residential building, four-star hotel, hostel, museum, shop and traditional dance house. For each of these functions, two kinds of room are considered with regard to vibrations. In the first type of room, people will be residing during both the day and the night - this is why more restrictive requirements are needed. The second type of room is the kind in which people only stay during the day and they are only in a vertical posture (sitting or staying); thus, they do not need such stringent requirements. Requirements for both types of rooms are listed in Table 3.

Table 3. Vibrational requirements for different types of room (own source)

\begin{tabular}{|l|l|l|}
\hline Building type & $\begin{array}{l}\text { HPVR } \\
\text { values [-] }\end{array}$ & Description \\
\hline $\begin{array}{l}\text { Residential, } \\
\text { four star hotel, } \\
\text { hostel }\end{array}$ & $0-0.99$ & Vibration not perceptible \\
\cline { 2 - 3 } & $1.0-1.4$ & $\begin{array}{l}\text { Vibration perceptible but } \\
\text { not harmful }\end{array}$ \\
\cline { 2 - 3 } $\begin{array}{l}\text { Museum, } \\
\text { shop, } \\
\text { traditional } \\
\text { dance house }\end{array}$ & $0-0.99$ & Harmful vibration \\
\cline { 2 - 3 } & $1.0-4.0$ & $\begin{array}{l}\text { Vibration not perceptible } \\
\text { not harmful perceptible but }\end{array}$ \\
\cline { 2 - 3 } & $>4$ & Harmful vibration \\
\hline
\end{tabular}

\subsubsection{Criterion - Acoustic comfort}

The acoustic requirements for different types of room are determined by Polish standard [39]. This standard does not apply to interiors with special acoustics, such as concert or theatre halls, which require an individual approach, but it applies to ordinary rooms in public and residential buildings in which good acoustic conditions determine the comfort. Requirements are expressed by means of:

- reverberation time $(\mathrm{T})$ and speech transmission index (STI) - in the case of rooms whose main function is based on verbal communication;

- reverberation time (T) or acoustic absorption (A) for other rooms.

There are no requirements in the newest version of the acoustic standard which would specify sound level inside the room (residential, office etc.). The requirements do not apply to different types of room but to internal and external partitions such as external and internal walls, floors, roof etc. Despite this, the owners of high-class hotels especially require acoustic comfort regardless of the source of noise. This is why for the purposes of the article, the sound level values for rooms were adopted in accordance with the old guidelines [40] and are listed in Table 4 .
Table 4. Acoustic requirements for different types of room (own source)

\begin{tabular}{|c|c|c|}
\hline Building type & Time of day & Sound level [dB] \\
\hline residential, & Day & $<35$ \\
\cline { 2 - 3 } hostel & Night & $<25$ \\
\hline four star hotel & Day & $<25$ \\
\cline { 2 - 3 } & Night & $<25$ \\
\hline museum, shop, & Day & $<55$ \\
\hline traditional dance house & Day & $<67$ \\
\hline
\end{tabular}

It is worth noting that ensuring high level of acoustic comfort is a multi-stage process, and the most important step is the appropriate selection of materials for partitions

\section{Conclusions}

Adapting the historic object to new functions is an effective way to extend its life cycle. This multi-faceted process forces the decision maker to apply a multi-criteria approach in deciding about the new utility function for a historic building. A good strategy in this type of decision making process is to attempt to synthetically describe the problem in the form of a decision model, the analysis of which will allow the decision maker to choose the best solution in relation to the adopted criteria. This article has proposed a multi-criteria hybrid approach to select a new utility function as part of the planned adaptation of the historic 'Stara Polana' building in Zakopane. For this purpose, seven variants of functions were proposed as well as a set of decision criteria taking into account, apart from the social and financial aspects, the adaptation process of the historic building for its new utility functions, and environmental protection criteria in accordance with the idea of sustainable development, including the necessity to protect cultural heritage. In the first part of the discussion on this decision problem, the authors focused on the concept of building the structure of the model whilst taking into account the specific (for the analysed decision problem) relationships between the criteria and decision variants. They also proposed methods of structural analysis of the model in the form of a hybrid to use in the most complementary way. In the second part, the authors made a detailed description of environmental criteria based on meeting the requirements of the Małopolska Energy-Efficient Building Certificate and additional criteria for the comfort of use of the premises.

In the subsequent stages of the research, the remaining selection criteria will be described and, based on the collected data, a multi-criteria analysis will be carried out to select the best variant of the utility functions for the historic building in question.

\section{Literature}

1. Ustawa z dnia 23 lipca 2003 r. o ochronie zabytków i opiece nad zabytkami, Dz U. z 2003, nr 162, poz. 1568.

2. Kłoczkowski J., Ratajski S., Kultura a zrównoważony rozwój. Środowisko, ład przestrzenny, dziedzictwo, 
Polski Komitet do Spraw UNESCO, Warszawa (2009).

3. WCED Bruntland Commission, Our Common Future, Oxford University Press, Oxford (1987).

4. Konstytucji Rzeczpospolitej Polska.

5. Ustawa $\mathrm{z}$ dnia 27 kwietnia $2001 \mathrm{r}$. Prawo ochrony środowiska. Dz.U. $2001 \mathrm{nr} 62$ poz. 627.

6. Ustawa $\mathrm{z}$ dnia 27 marca 2003 r. o planowaniu i zagospodarowaniu przestrzennym. Dz.U. $2003 \mathrm{nr} 80$ poz. 717 .

7. Affelt W., Dziedzictwo techniki jako cząstka kultury, W stronę dziedzictwa zrównoważonego (cz.2), Ochrona Zabytków, (2009a), s. 53-82.

8. Terlikowski W., Wpływ wybranych zagadnień dotyczących budynków zabytkowych na logistykę procesu ich rewitalizacji, Logistyka, 3(2014), s. 6326-6334.

9. Skaldawski B., Chabiera A., Lisiecki A., System ochrony zabytków w wybranych krajach europejskich, kurier konserwatorski 11 (2011), s. 535.

10. Ocena energetyczna budynku $\mathrm{z}$ wykorzystaniem metod optymalizacji wielokryterialnej i wielopoziomowej. Rozprawa doktorska Fedorczak Cisak M. 2008.

11. Fedorczak - Cisak M., Furtak M., Romańska Zapała A., Wdrażanie dyrektywy EPDE w Polsce w aspekcie działań Politechniki Krakowskiej Małopolski Certyfikat Budynku Energooszczędnego, Przegląd Budowlany nr 6/2015, Warszawa 2015, ISSN 0033-2038.

12. Fedorczak-Cisak M., Furtak M., The development of energy-efficient construction in the Malopolska region by the projects SPIN. Malopolska Certified Energy-Efficient Building [w:]Recent Advances in Mechanics, Mechatronics and Civil, Chemical and Industrial Engineering. Proceedings of the 2015 International Conference on Civil Engineering, Zakynthos Island, Grecja, 2015, str. 201-208, ISBN: 978-1-61804-325-2, ISSN: 2227-4588.

13. https://mapy.zabytek.gov.pl/nid/

14. Ustawa z dnia 7 lipca 1994 r. Prawo budowlane. Dz. U. z 2017 r. poz. 1332, 1529, z 2018 r.

15. Rozporządzenie Ministra Infrastruktury i Budownictwa z dnia 14 listopada 2017 r. zmieniające rozporządzenie w sprawie warunków technicznych, jakim powinny odpowiadać budynki i ich usytuowanie.

16. PN-EN 12464-1 „Światło i oświetlenie. Oświetlenie miejsc pracy. Część 1: Miejsca pracy we wnętrzach"

17. Skłodowski M., Przykłady analizy wielokryterialnej w ocenie wartości i ochrony dziedzictwa kultury, pod redakcją Szmygina B., Systemy wartościowania dziedzictwa - stan badań i problemy, Lubelskie Towarzystwo Naukowe, Międzynarodowa Rada Ochrony Zabytków ICOMOS Politechnika Lubelska, Warszawa, Lublin (2015), s. 209-240.

18. Dytczak M., Ginda G., Wybrane wielokryterialne metody wartościowania uwzględniające trudno mierzalność cech zabytków, wew. pod red. Szmygina B., Systemy wartościowania dziedzictwa - stan badań i problemy, Lubelskie Towarzystwo Naukowe,
Międzynarodowa Rada Ochrony Zabytków ICOMOS Politechnika Lubelska, Warszawa, Lublin (2015), s. 39-59.

19. Radziszewska-Zielina E., Śladowski G., G., Sibielak M., Planning the reconstruction of a historic building by using a fuzzy stochastic network, "Automation in Construction”, Vol. 84, 2017, pp. 242-257.

20. Michnik J. Wielokryterialne metody wspomagania decyzji w procesie innowacji, Uniwersytet Ekonomiczny w Katowicach, Katowice (2013).

21. Ming-Lang Tseng, Using a hybrid MCDM model to evaluate firm environmental knowledge management in uncertainty, Applied Soft Computing 11 (2011) 1340-1352.

22. Gabus A., Fontela E., World Problems an Invitation to Further Thought within the Framework of DEMATEL, Battelle Geneva Research Centre, Switzerland Geneva (1972).

23. Saaty T. L., Decision Making with Dependence and Feedback: The Analytic Network Process, University of Pittsburgh, RWS Publications, (1996), ISBN.

24. Radziszewska-Zielina Elżbieta, Śladowski Grzegorz. 2017. Supporting the Selection of a Variant of the Adaptation of a Historical Building with the Use of Fuzzy Modelling and Structural Analysis. Journal of Cultural Heritage. vol. 26, (2017) 53-63.

25. Radziszewska-Zielina E., Śladowski G., Proposal of the Use of a Fuzzy Stochastic Network for the Preliminary Evaluation of the Feasibility of the Process of the Adaptation of a Historical Building to a Particular Form of Use, IOP Conference Series: Materials Science and Engineering, WMCAUS 2017, vol. 245, 2017.

26. Komfort użytkowania oraz klimat środowiska wewnętrznego budynków energooszczędnych $=$ The comfort using rooms and climate of the international environment of energy efficient buildings / Małgorzata Fedorczak-Cisak, Alicja KowalskaKoczwara // Materiały Budowlane. - 2014, Nr 6 (502), s. 97-100. - ISSN 0137-2971.

27. PN-EN 15251 Parametry wejściowe środowiska wewnętrznego dotyczące projektowania i oceny charakterystyki energetycznej budynków, obejmujące jakość powietrza wewnętrznego, środowisko cieplne, oświetlenie i akustykę.

28. PN-EN ISO 7730 Ergonomia środowiska termicznego.

29. EN ISO 7726 Ergonomia środowiska termicznego -Przyrządy do pomiaru wielkości fizycznych.

30. M.E. Gierke, R.R. Coerman, The biodynamics of human response to vibration and impact, Indust. Med. and Surg 32, 1963, 30-32

31. PN-B-02171:2017-06 evaluation of human exposure to vibration in buildings

32. ISO 2631-2, Guide to the evaluation of human exposure to whole body vibration. Part 2 - Vibration in buildings, 2003, International Organization for Standardization.

33. ISO 10137 Bases for design of structures Serviceability of buildings and walkways against vibration, 2007, International Organization for Standardization 
34. Tamura Y., Kawana S., Nakamura O., Kanda J. \& Nakatà S., Evaluation perception of wind-induced vibration in buildings. Structures \& Buildings, 159, pp. 1-11, 2006.

35. Kwok K. C. S, Hitchcock P. A., Burton M. D. Perception of vibration and occupant comfort in wind-excited tall buildings. Journal of Wind Engineering and Industrial Aerodynamics, Vol. 97, Issues 7-8, September-October 2009, pp. 368-380. doi:10.1016/j.jweia.2009.05.006

36. Waddington D. C, Woodcock J., Peris E., Condie J., Sica G., Moorh o u s e A. T., \& S t e e 1 e A. Human response to vibration in residential environments. J. Acoust. Soc. Am. 135,82 (2014); http://dx.doi.org/10.1121/1.483 6496.

37. Marioka M., Griffin M. J. Difference thresholds for intensity perception of whole-body vertical vibration: Effect of frequency and magnitude. J. Acoust. Soc. Am. 107 (1), January 2000, pp. 620-624.

38. Kawecki J., Stypuła K. Ensuring vibrational comfort for people in buildings exposed for transport impact. (in Polish). Publishing House of Cracow University of Technology, Cracow 2013

39. PN-B-02151-4:2015-06 Building acoustics. Noise protection in buildings. (in Polish).

40. Norma PN-B-02151-3;1999 Building acoustics. Noise protection in buildings. (in Polish).

41. Maciąg E., Kuzniar K., Tatara T. (2015) « Response Spectra of the Ground Motion and Building Foundation Vibrations Excited by Rockbursts in the LGC Region ». Earthquake Spectra, Vol. 32, No 3, 1769-1791, August 2016, ISSN 8755-2930.

42. Tatara T., Pachla F., Kuboń P. «Experimental and numerical analysis of an industrial TC Tower». Biuletyn of Erthquake Engineering, ISSN : 1570761X (Pront version) ; 1573-1456 (online clectronic version). DOI : 10.1007/s10518-016-0053-y. 